\title{
Characterization of Limestone as Raw Material to Hydrated Lime
}

\author{
Rajeb Salem Hwidi ${ }^{1}$, Tengku Nuraiti Tengku Izhar ${ }^{1, *}$, and Farah Naemah Mohd Saad ${ }^{1}$ \\ ${ }^{1}$ School of Environmental Engineering, Universiti Malaysia Perlis, Kompleks Pusat Pengajian Jejawi \\ 3, Arau 02600, Perlis, Malaysia.
}

\begin{abstract}
In Malaysia, limestone is essentially important for the economic growth as raw materials in the industry sector. Nevertheless, a little attention was paid to the physical, chemical, mineralogical, and morphological properties of the limestone using X-ray fluorescence (X$\mathrm{RF}$ ), X-ray diffraction (X-RD), Fourier transform infrared spectroscopy (FTIR), and Scanning electron microscopy / energy dispersive x-ray spectroscopy (SEM-EDS) respectively. Raw materials (limestone rocks) were collected from Bukit Keteri area, Chuping, Kangar, Perlis, Malaysia. Lab crusher and lab sieved were utilized to prepare five different size of ground limestone at $(75 \mu \mathrm{m}, 150 \mu \mathrm{m}, 225 \mu \mathrm{m}, 300$, and $425 \mu \mathrm{m})$ respectively. It is found that the main chemical composition of bulk limestone was Calcium oxide $(\mathrm{CaO})$ at $97.58 \mathrm{wt} \%$ and trace amount of $\mathrm{MnO}, \mathrm{Al}_{2} \mathrm{O}_{3}$, and $\mathrm{Fe}_{2} \mathrm{O}_{3}$ at $0.02 \%, 0.35 \%$, and $0.396 \%$ respectively. XRD diffractograms showed characteristic peaks of calcite and quartz. Furthermore, main FTIR absorption bands at 1,419, 874.08 and $712.20 \mathrm{~cm}^{-}$ ${ }^{1}$ indicated the presence of calcite. The micrographs showed clearly the difference of samples particle size. Furthermore, EDS peaks of $\mathrm{Ca}, \mathrm{O}$, and $\mathrm{C}$ elements confirmed the presence of $\mathrm{CaCO}_{3}$ in the samples.
\end{abstract}

\section{Introduction}

In Malaysia, limestone is characterized by wide karstification with the development of a complex and large network of caves [1]. Limestone hills naturally with sharp sides and rising up to many hundred meters above the flat alluvial plains are a well-known feature of the Malaysian landscape. Most of these alluvial plains are underlain at moderately shallow depths by the same limestone that forms, the prominent hills. The detection of rich tin deposits in the alluvium has led to the improvement of several urban centers adjacent to and later increasing on to the former mining regions [1].

Limestone is mainly composed of calcium carbonate mineral $\mathrm{CaCO}_{3}$. This compound is one of the most common materials among the chemically precipitated sedimentary rocks [2]. Biological and also biochemical methods are the main processes in the carbonate sediments formation. Nevertheless, the inorganic precipitation of calcium carbonate from seawater can also happen [3]. After $\mathrm{CaCO}_{3}$ formation, physical and chemical processes of diagenesis can significantly change the characteristics of $\mathrm{CaCO}_{3}$.

* Corresponding author: nuraiti@unimap.edu.my 
Limestone is widely used in architectural applications for walls, decorative trim and veneer. It is less frequently used as a sculptural material, because of its porosity and softness. However, it is a common base material. It may be found in both bearing (structural) and veneer applications. In Malaysia, limestone is recently used in removal of heavy metals $(\mathrm{Pb}, \mathrm{Cd}, \mathrm{Cu}, \mathrm{Ni}, \mathrm{Zn}$, and $\mathrm{Cr}(\mathrm{III}))$ from water [4]. It's found that limestone was able to remove more than $90 \%$ of heavy metals from polluted water [4].

Another important use of limestone (after converting to hydrated lime) is mitigation of poisonous and dangerous gases emission. Lime treatment reduces odors, particularly hydrogen sulfide, which is not only a nuance odor but also can be very dangerous if localized high concentrations build up [5]. In addition to high $\mathrm{pH}$, lime provides free calcium ions, which react and form complexes with odorous sulfur species such as hydrogen sulfide and organic mercaptans $[5,6]$.

In the current work, the characterization of limestone as a raw material of hydrated lime was conducted using wide range of analysis to investigate the physical, chemical, mineralogical, and morphological properties of limestone.

\section{Materials and methods}

\subsection{Sample location}

The main material used in this work is the limestone, which was obtained from Bukit Keteri area, Chuping, 02450 Kangar, Perlis, Malaysia, 6.5035795,100.26139 GPS coordination.

\subsection{Sample preparation}

In order to prepare the samples, limestone were crashed using lab crasher. The ground limestone samples were sieved into five different sizes at $75 \mu \mathrm{m}, 150 \mu \mathrm{m}, 225 \mu \mathrm{m}, 300$, and $425 \mu \mathrm{m}$ as shown in Figure 1.
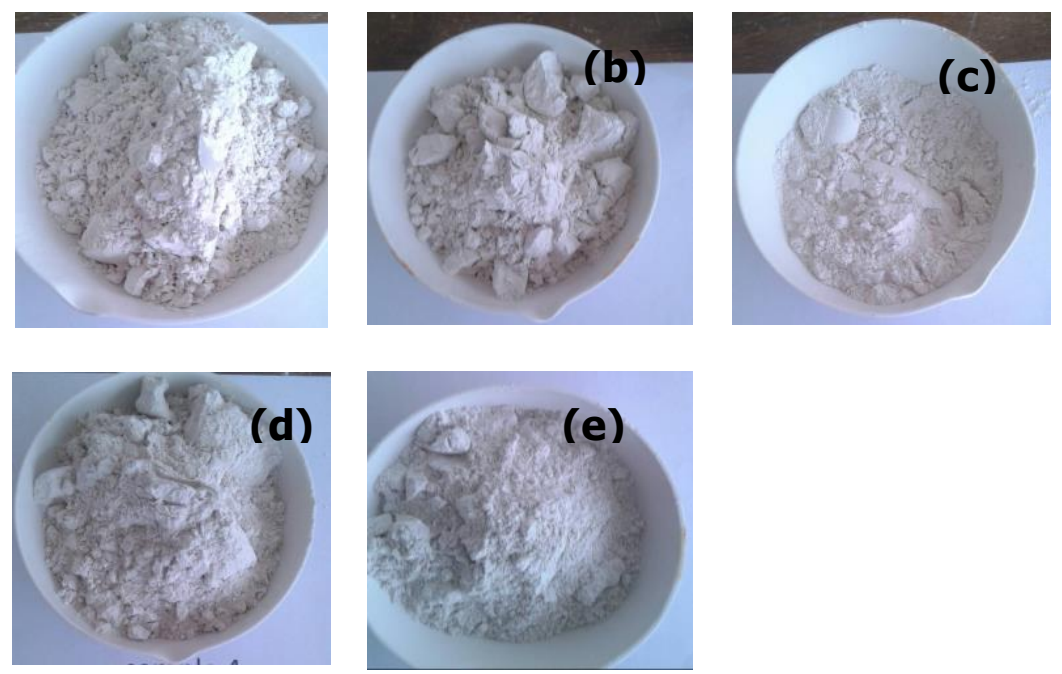

Fig. 1. Optical images of limestone samples at (a) $75 \mu \mathrm{m}$, (b) $150 \mu \mathrm{m}$, (c) $250 \mu \mathrm{m}$, (d) 300, and (e) $425 \mu \mathrm{m}$. 


\subsection{Sample characterization}

After preparation of limestone samples, the mineralogical, chemical, physical and morphological properties of the hydrated lime samples were characterized and evaluated using X-ray fluorescence (X-RF) spectrometry, X-ray diffraction (X-RD), Fourier Transform Infrared Spectroscopy (FTIR), and Scanning Electronic Microscopy (SEM) attached with Energy Dispersive X-ray analysis (EDS) respectively.

\subsubsection{X-ray fluorescence $(X-R F)$}

X-rays fluorescent (XRF) was conducted using XRF spectrometer (Model MiniPAL 4 Brand: PANanalytical PW4030). X-RF analysis was carried out to determine elemental composition of the materials, which is based on the principle of individual atoms. When the sample is irradiated by X-rays, it measures the individual component wavelengths of the fluorescent emission produced by the sample.

\subsubsection{X-ray diffraction $(X-R D)$}

First, the specimen was pressed in stainless steel holder and then the Quantitative mineralogical evaluation was conducted by X-ray diffraction (X-RD) using $\mathrm{CuK} \alpha$ radiation, $0.02^{\circ}$ step size, $3 \mathrm{~s}$ counting time, $10^{\circ} \mathrm{b} 2 \theta \mathrm{b} 80^{\circ}$ range and Rietveld refinement method (X'Pert MPD - PANalytical X-ray B.V.). This method is designed to obtain a high quality diffraction data, associated with ease of use and flexibility to quickly switch to different applications.

\subsubsection{Fourier transform infrared spectroscopy (FTIR)}

Transmission FTIR spectra of composite films were recorded from thin $\mathrm{KBr}$ disc of the samples with Perkin Elmer 2000 FTIR spectrophotometer at room temperature. The samples were scanned from 4000 to $400 \mathrm{~cm}^{-1}$ with resolution of $0.4 \mathrm{~cm}^{-1}$. By using FTIR, the functional groups in a molecule can be identified.

\subsubsection{Scanning electron microscopy / energy dispersive $x$-ray spectroscopy (SEM- EDS)}

The morphology and elemental chemical composition of the limes were determined respectively by scanning electronic microscopy (SEM) - using secondary electrons detector - and energy dispersive X-ray analysis (EDS) (LEO Stereoscan 440). The specimens were coated by an extremely thin layer of gold $(1.5-3 \mathrm{~nm})$ using sputter coater machine. The purpose of specimens coating is to avoid the poor resolution of the image and also to prevent the electrostatic charging during test. The test was conducted at $1000 \mathrm{x}$ magnification.

\section{Results and discussions}

The chemical composition of bulk limestone is listed in Table 1. The high contents of Calcium oxide $(\mathrm{CaO})(97.58 \mathrm{wt} . \%)$ in the sample indicated that the sample was high limestone purity [7], but silica constituted the common impurity $(0.90 \mathrm{wt.} \%)$. The high percentage of the main element $(\mathrm{CaO})$ in the specimen showed high enrichment factor thus concerning cement as the main contributing source to airborne particulate matter in these 
factories and environs. This has a clear environmental implication, which should be of interest to the environmental protection agency and also to the government. The occurrence of faint magnesium oxide in the sample bears witness to the presence of trace amounts of smectite [7, 8]. It is also found that a trace amount of $\mathrm{Al}_{2} \mathrm{O}_{3}, \mathrm{Fe}_{2} \mathrm{O}_{3}$, and $\mathrm{SrO}$ elements are existed in the sample.

Table 1. Chemical composition of bulk limestone sample (wt.\%).

\begin{tabular}{|c|c|c|c|c|c|c|c|c|c|c|c|c|}
\hline $\begin{array}{c}\text { Chemical } \\
\text { Compound } \\
\text { s }\end{array}$ & $\begin{array}{c}\mathrm{Al} \\
\mathrm{Al}_{2} \mathrm{O} \\
3 \\
\end{array}$ & $\begin{array}{c}\mathrm{Si} \\
\mathrm{SiO} \\
2\end{array}$ & $\begin{array}{c}\mathrm{Ca} \\
\mathrm{CaO}\end{array}$ & $\begin{array}{c}\mathrm{Ti} \\
\mathrm{TiO} \\
2\end{array}$ & $\begin{array}{c}\mathrm{Mn} \\
\mathrm{Mn} \\
\mathrm{O}\end{array}$ & $\begin{array}{c}\mathrm{Mg} \\
\mathrm{Mg} \\
\mathrm{O}\end{array}$ & $\begin{array}{c}\mathrm{Fe} \\
\mathrm{Fe}_{2} \mathrm{O} \\
3\end{array}$ & $\begin{array}{c}\mathrm{Cu} \\
\mathrm{CuO}\end{array}$ & $\begin{array}{c}\mathrm{Sr} \\
\mathrm{SrO}\end{array}$ & $\begin{array}{c}\mathrm{Ru} \\
\mathrm{RuO} \\
2\end{array}$ & $\begin{array}{c}\mathrm{Eu} \\
\mathrm{Eu}_{2} \mathrm{O} \\
3\end{array}$ & $\begin{array}{c}\text { Tota } \\
1\end{array}$ \\
\hline Weight $\%$ & 0.35 & 0.90 & $\begin{array}{c}97.5 \\
8\end{array}$ & 0.13 & 0.02 & 0.01 & 0.395 & $\begin{array}{c}0.06 \\
5\end{array}$ & $\begin{array}{c}0.09 \\
2 \\
\end{array}$ & 0.37 & 0.08 & 100 \\
\hline
\end{tabular}

Fig. 2 shows the XRD diffractograms of the representative limestone samples, indicating the presence of characteristic peaks of calcite as identified by the distinctive reflections at 3.85-3.86 $\mathrm{A}^{\circ}$ (102), $3.03 \mathrm{~A}^{\circ}$ (100), $2.84 \mathrm{~A}^{\circ}$ (006), $2.49 \mathrm{~A}^{\circ}(110), 2.28 \mathrm{~A}^{\circ}$ (113), $2.09 \mathrm{~A}^{\circ}$ (202), $1.97 \mathrm{~A}^{\circ}$ (108), $1.87 \mathrm{~A}^{\circ}$ (116) and $1.60 \mathrm{~A}^{\circ}$ (212). Furthermore, the sample showed additional peaks prevailing at 3.33-3.34 $\mathrm{A}^{\circ}(101), 1.54 \mathrm{~A}^{\circ},(211), 1.37 \mathrm{~A}^{\circ}$ (203) and $1.28 \mathrm{~A}^{\circ}$ (104) showed the presence of quartz [7]. Detailed clay mineralogy was investigated and identified by the characteristic reflections according to Moore and Reynolds [9].

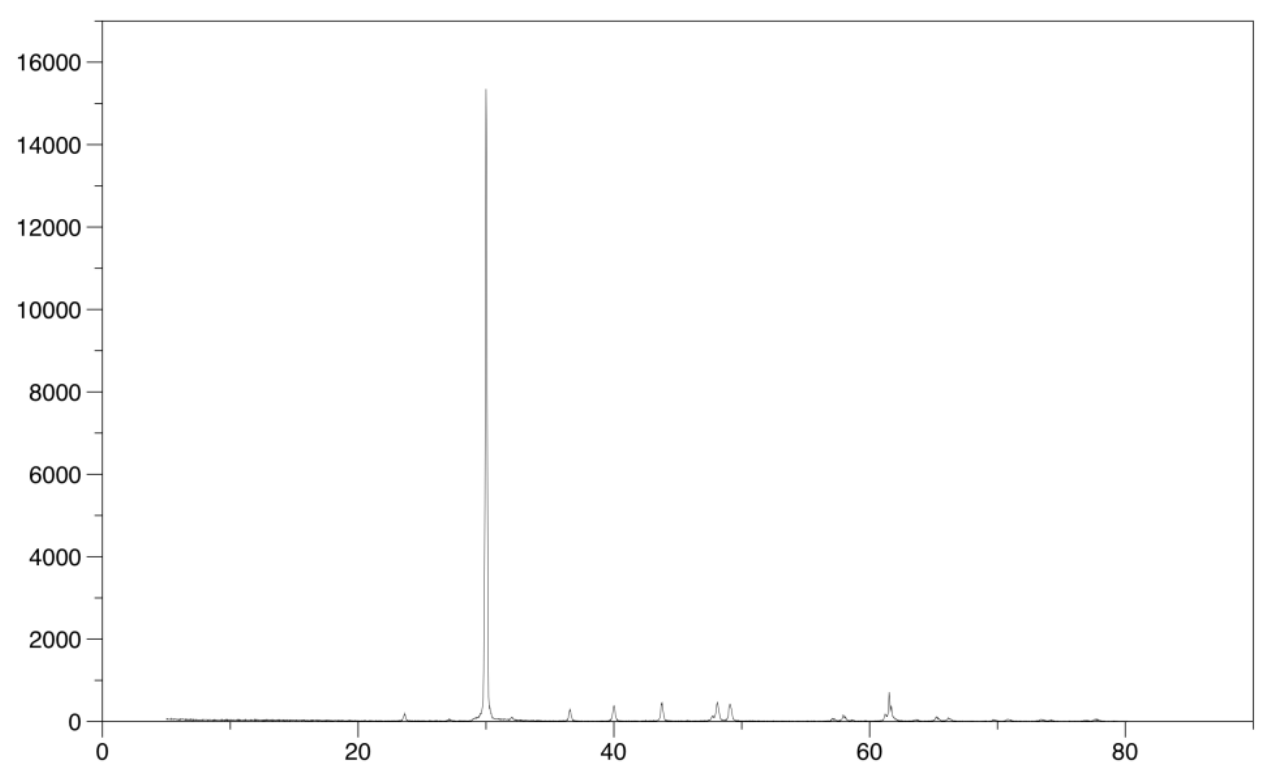

Fig. 2. X-RD of the limestone sample.

Fig. 3 shows the FTIR spectrum of the limestone sample. It shows the characteristic bands of calcite at 1,419,874.08 and $712.20 \mathrm{~cm}^{-1}$. The spectrum peaks appearing at 1,799 and $2,513.04 \mathrm{~cm}^{-1}$ are also an indication of the presence of calcite [10-13]. These data indicate that the studied limestone is mainly composed of calcium in the form of calcite as identified by its main absorption bands [13]. The reference bands observed at 1,419, 874.08 and $712.20 \mathrm{~cm}^{-1}$ can be assigned to the asymmetric stretching, out-of-plane bending and inplane bending modes of $\mathrm{CO}_{3}{ }^{2-}$, respectively [14]. Gunasekaran and Anbalagan mentioned in their research that the observed out-of-plane bending mode occurs at $877 \mathrm{~cm}^{-1}$ for ${ }^{12} \mathrm{C}$. 
This band shifts to lower wave numbers for other isotopes of carbon $\left({ }^{13} \mathrm{C}\right.$ and $\left.{ }^{14} \mathrm{C}\right)$. However, limestone sample has a splitting band at $874.71 \mathrm{~cm}^{-1}$ [12]. This clearly indicates that there is no isotopic shift. According to the author in his research, the bands observed at 1,799 and $2,513 \mathrm{~cm}^{-1}$ are attributed to the $\mathrm{v}_{1}+\mathrm{v}_{4}$ combination mode. Moreover, the stretching vibrations of the surface hydroxyl groups ( $\mathrm{Si}-\mathrm{Si}-\mathrm{OH}$ or Al-Al-OH) were found at $3,544.52$ and $3,619.73 \mathrm{~cm}^{-1}$ [15]. Infrared techniques have been frequently used for the identification of clay minerals $[10,11]$ as well as the natural calcite minerals [12].

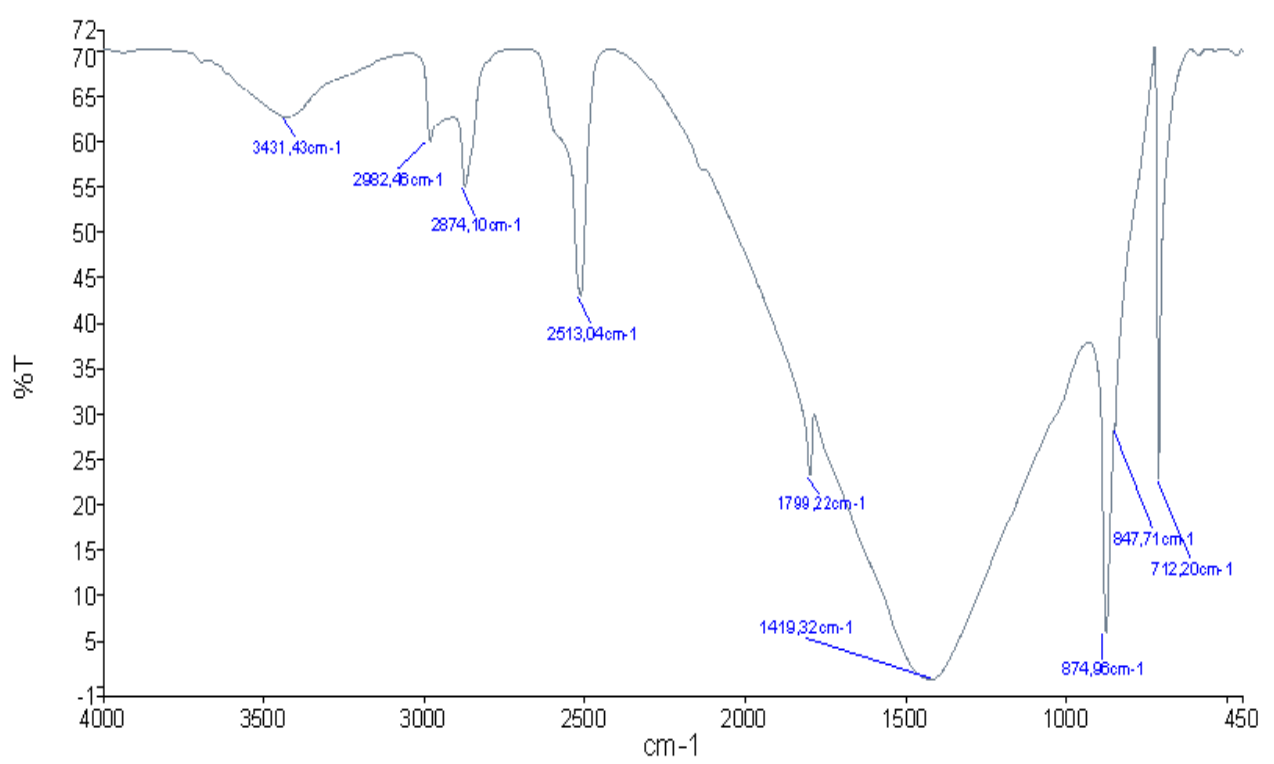

Fig. 3. FTIR spectrum of bulk limestone sample.

The observation of the morphology using the scanning electron microscope of the limestone, with three different sizes (fine, med, and coarse size) is reported in Fig. 4 a, b, and $c$ respectively. It's clearly observed that the samples have different sizes due to different grinding and sieving processing applied on the samples. The samples show compact morphology, so the samples have less porous and the carbonates represent the main phase with calcite peaks [16]. Furthermore, the samples have morphology with angular grains of quartz size, covered with fine particles and the grains of calcite appear clearly. This analysis of the morphology by SEM is associated by EDS analysis of the elements exist on choised line on area with maximum amount of informations as it is showing in Fig. 4 and Table 2 respectively. The presence of $\mathrm{Ca}$, $\mathrm{O}$, and $\mathrm{C}$, as major element confirms the importance of carbonate phases, $\mathrm{CaCO}_{3}$ compound in the samples (Table 2). 

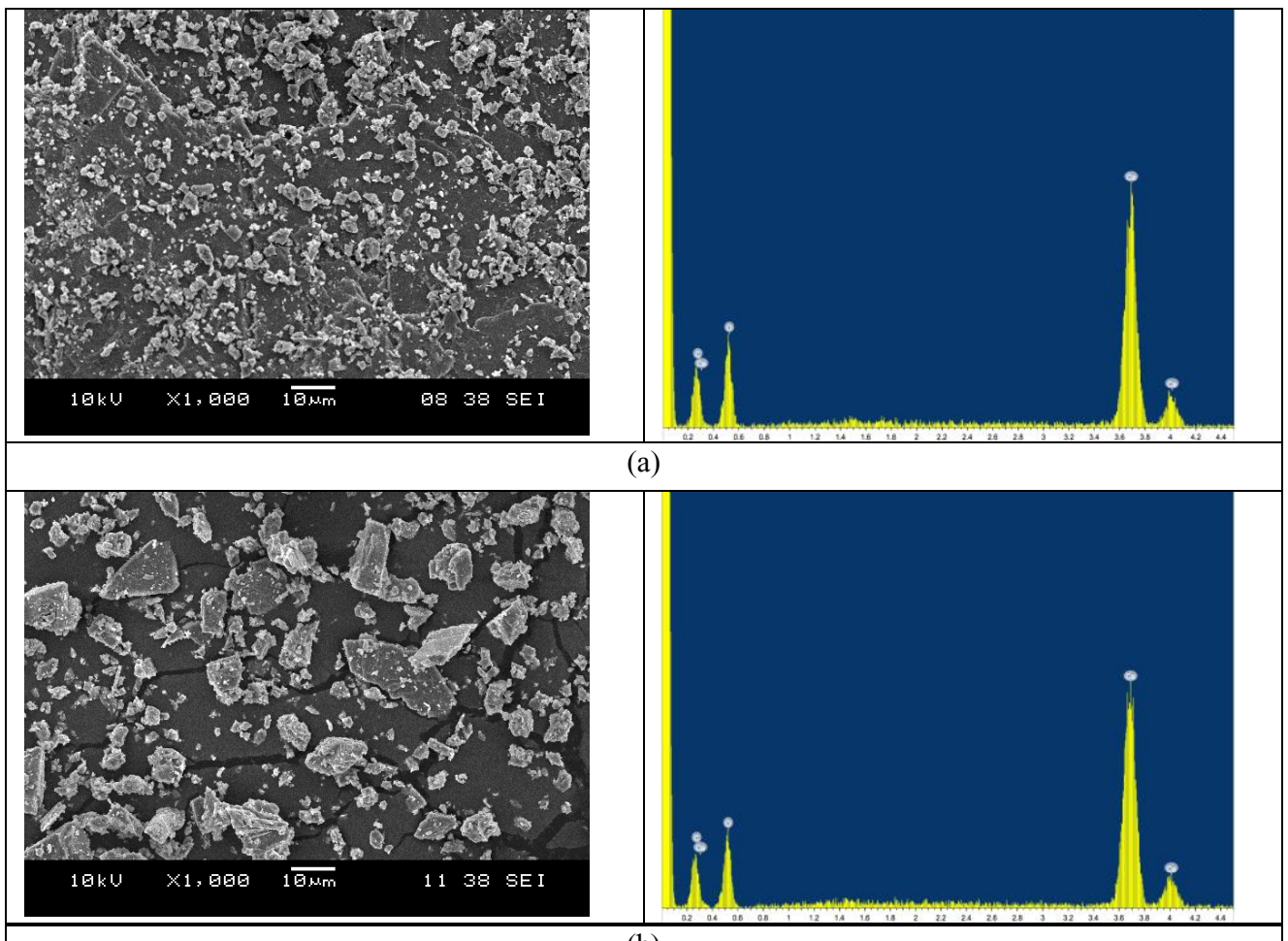

(b)
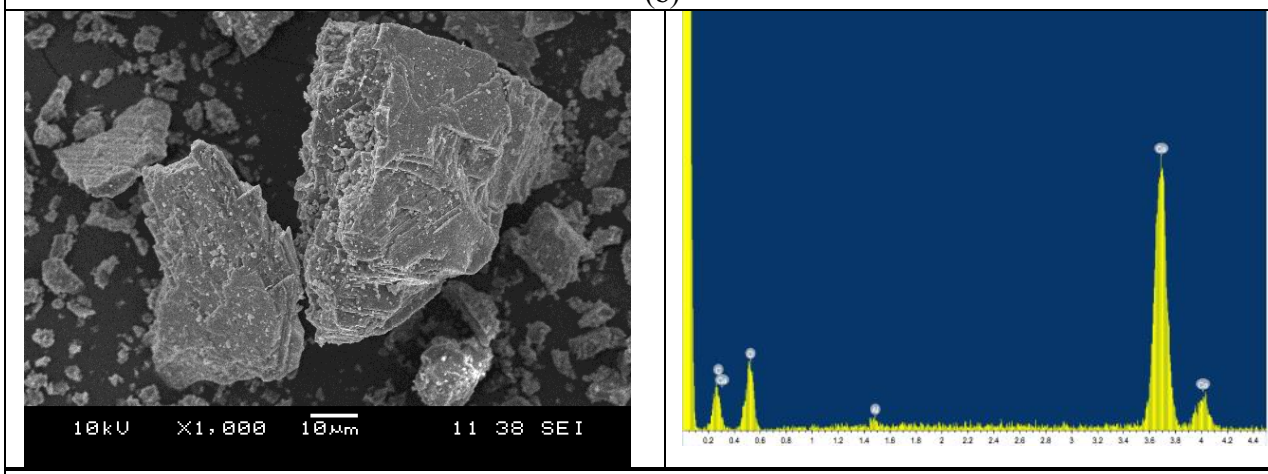

(c)

Fig. 4. SEM-EDS of lime stone samples at (a) fine size $75 \mu \mathrm{m}$ (b) medium size $225 \mu \mathrm{m}$ and (c) coarse size $425 \mu \mathrm{m}$.

Table 2. Elemental analysis of limestone samples.

\begin{tabular}{|l|l|c|}
\hline \multicolumn{1}{|c|}{ Element } & Weight $\%$ & Atomic $\%$ \\
\hline $\mathrm{C} \mathrm{K}$ & 17.33 & 27.63 \\
\hline $\mathrm{O} \mathrm{K}$ & 45.69 & 54.70 \\
\hline $\mathrm{Ca} \mathrm{K}$ & 36.98 & 17.67 \\
\hline \multicolumn{3}{|c|}{ Total $=100$} \\
\hline
\end{tabular}




\section{Conclusions}

In this work, it can be concluded that the limestone samples obtained from Bukit Keteri area had high limestone purity due to high calcium oxide and low silica percentage in the samples. Calcite mineral was identified by X-ray diffractograms and FTIR spectrum. Furthermore, the $\mathrm{Ca}, \mathrm{O}, \mathrm{C}$ elements proved the presence of $\mathrm{CaCO}_{3}$ in the samples (as shown in SEM-EDS micrographs).

\section{References}

1. B. K. Tan, Bull. Eng. Geol. Environ. 35, 57 (1987)

2. S. Cornelius, Jr. Hurlbut, K. Cornelis, Dana's Manual of Mineralogy, Wiley: New York, (1977)

3. M.E. Tucker, Sedimentary Petrology: An Introduction to the Origin of Sedimentary Rocks, Blackwell Scientific Publishing: Malden, (2001)

4. H.A. Aziz, M.N. Adlan, K.S. Ariffin, Bioresour. Technol. 99, 1578 (2008)

5. R.J. Fairweather, M.A. Barlaz, J. Environ. Eng. 124, 353 (1998)

6. R. Anderson, J.R. Jambeck, G.P. McCarron, Environmental Research and Education Foundation (2010)

7. A. Sdiri, T. Higashi, T. Hatta, F. Jamoussi, N. Tase, Environmental Earth Sciences 61, 1275 (2010)

8. M. Felhi, A. Tlili, M.E. Gaied, M. Montacer, Appl Clay Sci 39, 208 (2008)

9. D.M. Moore, R.C. Reynolds, Quantitative analysis. In: Moore DM, Reynolds $R C J r$ (eds) X-Ray diffraction and the identification and analysis of clay minerals, Oxford Univ Press: Oxford, 272, (1989)

10. Y.S. Al-Degs, M.I. El-Barghouthi, A.A. Issa, M.A. Khraisheh, G.M. Walker, Water Res 40, 2645 (2006)

11. S.N. Preeti, B.K. Singh, Bull Mater Sci 30, 235 (2007)

12. S. Gunasekaran, G. Anbalagan, Spectrochim. Acta, Part A 68, 656 (2007)

13. S. Gunasekaran, G. Anbalagan, S. Pandi, J Raman Spectrosc 37, 892 (2006)

14. N.V. Vagenas, A. Gatsouli, C.G. Kontoyannis, Talanta 59, 831 (2003)

15. M. Hajjaji, S. Kacim, A. Alami, A. El Bouadili, M. El Mountassir, Appl Clay Sci 20, 1 (2001)

16. K. Besnard, D.E.A. Hydrologie, G. Hydrogéologie, G.F. Hydrologie, Hydrogéologie, Géostatistique et Géochimie, Université Paris-Sud. (2000) 